\title{
The relative importance of climate change and population growth for exposure to future extreme droughts
}

\author{
Oleg Smirnov ${ }^{1}$ (D) Minghua Zhang ${ }^{2} \cdot$ Tingyin Xiao $^{2} \cdot$ \\ John Orbell ${ }^{3} \cdot$ Amy Lobben ${ }^{4}$ - Josef Gordon ${ }^{4}$
}

Received: 6 July 2015 / Accepted: 4 June 2016 /Published online: 9 June 2016

(C) The Author(s) 2016. This article is published with open access at Springerlink.com

\begin{abstract}
The human consequences of drought are normally addressed in terms of "water scarcity" originating from human water use. In these terms, a common prediction to the next few decades is that population growth, not climate change, will be the dominant factor determining numbers living under such scarcity. Here we address the relative importance of increasing human caused extreme drought and increasing population for numbers of humans likely to be directly exposed in the future to such drought. Using the Standardized Precipitation Evapotranspiration Index (SPEI) in conjunction with an ensemble of 16 CMIP5 climate models we find that, by 2081-2100 under the high emissions scenario RCP 8.5 , average worldwide monthly population exposed to extreme drought (SPEI < -2) will increase by 386.8 million to 472.3 million ( $+426.6 \%$ from the current 89.7 million). Anthropogenic climate change is responsible for approximately 230.0 million (59.5\%) of that increase with population growth responsible for only 35.5 million (9.2\%); the climate change-population growth interaction explains the remaining 121.1 million (31.4\%). At the national level, 129 countries will experience increase in drought exposure mainly due to climate change alone; 23 countries primarily due to population growth; and 38 countries primarily due to the interaction between climate change and population growth. Given inherently large uncertainties, projections of future climate impacts should be accepted with caution especially those directed to the regional level, to future population trends, and, of course, where technological, social and security changes are possible.
\end{abstract}

Electronic supplementary material The online version of this article (doi:10.1007/s10584-016-1716-z) contains supplementary material, which is available to authorized users.

Oleg Smirnov

oleg.smirnov@stonybrook.edu

1 Department of Political Science, Stony Brook University, Stony Brook, NY 11794, USA

2 School of Marine and Atmospheric Sciences, Stony Brook University, Stony Brook, NY 11794, USA

3 Institute of Cognitive and Decision Sciences, University of Oregon, Eugene, OR 97403, USA

4 Department of Geography, University of Oregon, Eugene, OR 97403, USA 
Among the many predicted geophysical consequences of climate change for human populations (IPCC 2013), we know that extreme droughts have the potential for particularly severe damage to human economies, livelihoods and health — even beyond their impact on natural resources and ecosystems (IPCC 2014; Kelley et al. 2015; Reyna 2010). Drought ranks first among natural disasters in terms of the number of people affected (Mishra and Singh 2010), and between 1992 and 2001 it was by a substantial margin the primary cause of death $(277,574$ deaths), followed by floods $(96,507)$, earthquakes $(77,756)$, and storms $(60,447)$ (Dilley 2005).

Drought frequency is predicted to increase in the next several decades (IPCC 2014) and humans' exposure to water scarcity is likely to be increased simply through population growth (United Nations, 2013; Watts et al. 2015). But population growth and drought frequency might have independent effects on numbers so exposed, and those effects might vary from place to place. Absent drought, population growth is likely to put pressure on supplies of water, but absent population growth, increased drought could well do the same. Here we address human exposure to future droughts caused by the separate impacts of (a) population growth and (b) increased incidence of droughts due to climate change, and by (c) the combined influence of the two through their interaction.

Current hydrological literature often focuses on "water scarcity" (the bottom line for human populations rather than drought), in particular per capita water availability (Arnell 2004; Arnell et al. 2011; Gosling and Arnell 2013; Kummu et al. 2010) or a withdrawals-to-availability ratio (Gosling and Arnell 2013; Hanasaki et al. 2013; Vörösmarty et al. 2000). The impact of such scarcity on particular populations is then evaluated in terms of the numbers of people falling below a threshold value of water availability (e.g., $1000 \mathrm{~m}^{3} /$ capita/year) or that exceed a certain withdrawals-to-availability ratio (exceeding 0.4 is seen as water stress or severe water limitation). The emerging finding from this literature (Arnell and Lloyd-Hughes 2014; Arnell 2004; Arnell et al. 2011; Gerten et al. 2011; Rockström et al. 2009; Vörösmarty et al. 2000)and, consequently, from the IPCC report (IPCC 2014) - is that "population change explains the larger part of the overall change in water scarcity" (Schewe et al. 2014). For policy-makers the finding that future water scarcity "will be driven primarily by population growth and only secondarily by climate change" (Gerten et al. 2011) appears to undermine the importance of nations' emissions cuts relative to alternative policies (such as socioeconomic development) that are widely recognized as resulting in slower population growth.

In the present paper we use a measure of drought based on the multiscalar Standardized Precipitation Evapotranspiration Index (SPEI) (Vicente-Serrano et al. 2009) in conjunction with the Coupled Model Intercomparison Project Phase 5, or CMIP5 (Taylor et al. 2011) climate models to address populations' future direct exposure to such drought. This measure's calculation uses the monthly difference between precipitation $(\mathrm{P})$ and potential evapotranspiration (PET) instead of monthly precipitation as in the standardized precipitation index (SPI) (McKee et al. 1993). This difference between P and PET describes the water balance of the soil (Thornthwaite 1948). Although other drought indices are based on water balance - notably the Palmer drought severity index (PDSI) (Palmer 1965)—SPEI can represent different time scales. At longer timescales (12 months or more), it has been shown to correlate with the self-calibrating PDSI for a set of observatories with different climate characteristics located in different parts of the world (Vicente-Serrano et al. 2009). In the present paper, we calculate the accumulated difference between $\mathrm{P}$ and PET in the previous 24 months. To capture the frequency and duration of drought, we define "extreme drought" as the environmental condition for SPEI $<-2$, a common threshold value (Centre for Ecology and Hydrology 2016; 
Potop et al. 2013; Törnros and Menzel 2014). This condition may cause devastating social impacts through crop and pasture losses, health and extreme fire risks (Svoboda et al. 2002).

We define populations' exposure to extreme drought as the total number of people, in the world or in a country, living in grid cells where SPEI $<-2$. In this respect, we do not model the agricultural, economic, security and other social impacts of water shortages on human populations. To our knowledge, however, modeling national populations' exposure to future extreme droughts based on SPEI has yet to be done in the context of CMIP5 climate models and our paper attempts to fill that gap.

\section{Modeling exposure to extreme droughts in the future}

Predictions of droughts through the rest of the twenty-first century are derived from an ensemble of 16 CMIP5 coupled climate models (Taylor et al. 2011) - each constructed at a different modeling center - specified under the conventional four Representative Concentration Pathways (Moss et al. 2010; Vuuren et al. 2011). See Supplementary Table 2 for a description of the employed 16 models. Consistent with numerous other studies, we focus on the low emissions RCP 4.5 and high emissions RCP 8.5 (results for RCP 2.6 and RCP 6.0 are available in the replication dataset online). Notice that any uncertainty associated with these scenarios is "inherited" by our projections of drought exposure. The low emissions RCP 4.5, for instance, may be unrealistic given the current emissions trajectory; however, the results based on this scenario may still be useful as a benchmark against which to evaluate an alternative such as the high emissions RCP 8.5 .

Because we want to isolate climatic changes dependent on the respective RCPs, both the 4.5 and 8.5 projections used here are based on the same medium fertility population growth scenario, an approach employed by previous studies (Hinkel et al. 2013). In general, under the RCP 8.5/A2r population growth model, the population exposure values are higher than the medium fertility scenario by about $10 \%$ (see Supplementary Tables 9 and 10 for comparison for the world total as well as for individual nations). For each of the 16 models, the constructed data are interpolated to a $2^{\circ} \times 2^{\circ}$ grid. Only the first available ensemble member of the 16 is adopted ("r1ilp1" ensemble). For each model, we generate monthly SPEI data for the period between January 2008 and December 2100. The calculation of future SPEI is based on the reference surface precipitation and temperature simulated by the models during 1955-2005. The future change is, therefore, relative to the present climate, which implicitly accounts for climate models' bias corrections, equivalent to the delta method (Maraun et al. 2010; Teutschbein and Seibert 2012).

The global population raster landscape was constructed utilizing the LandScan 2008 High Resolution Global Population Data Set (Bhaduri et al. 2007). We transformed the LandScan grid to a format that matches the climate data $2^{\circ} \times 2^{\circ}$ grid. The resulting population map has a 2184 x 4320 resolution matching the common climate data resolution of $91 \times 180$ by a factor of 24. Since the land mask can lead to a loss of certain coastal areas (and, thus, populations), all climate input files were used without the mask.

A national boundaries map was created on the basis of the Global Administrative Areas dataset (Hijmans et al. 2011) which we matched initially with the LandScan 2008 map and then aggregated to the common $2184 \times 4320$ grid format. The grid was verified and we found zero population loss; all individuals from the higher-resolution LandScan map were accounted for and assigned national identification values (see Supplementary Information for details). 
Notice that it is possible for the population of small nations to live within one or a small number of grid cells. For such countries, the observed exposure is binary: either everyone is exposed or no one is exposed to drought. While drought conditions typically affect larger geographic areas, for such countries it is still more sensible to describe our results using the probabilistic framework of the "expected" number of people exposed to drought. In addition, we describe our results by looking at 20-year periods (e.g., 2081-2100) which, in conjunction with an ensemble of 16 climate models, generates 3840 data points ( 240 months * 16 models) for each emissions scenario. Nevertheless, we emphasize that our projections for small nations are associated with a larger degree of uncertainty than are projections for nations that substantially exceed the size of a grid cell $\left(2^{\circ} \times 2^{\circ}\right)$.

The computational model is based on the United Nations medium fertility population growth scenario (United Nations, 2013) (producing a world population of approximately 10.5 billion by the end of the century). In addition, we construct a population growth scenario corresponding to the $\mathrm{A} 2 \mathrm{r}$ projection matching the RCP 8.5 projections (approximately 12 billion world population by the end of the century). Similar to the uncertainty inherent in climate models and emissions scenarios, the uncertainty associated with population growth projections should be recognized in our results. While the UN projections are commonly used in academic literature, growth trends may change due to unforeseen circumstances - such as wars, mass migration, natural disasters, and so on.

Because we use a one month time period in the simulation, we transform the annual growth rates to monthly growth rates using the following common formula, $G_{m}=\left(1+G_{y}\right)^{1 / 12}-1$, where $G_{m}$ is the monthly growth rate and $G_{y}$ is the annual growth rate. Each month, the population of each cell of the world grid grows at a rate equal to the monthly growth rate of the country to which it belongs (see Supplementary Information Figure 2 for an illustration). We acknowledge that this is the simplest possible assumption for population growth but point out that a number of other studies have used the same model, including a seminal paper (Arnell 2004). (See Supplementary Information for further technical details about our calculations of national populations' exposure to extreme drought.)

Finally, we note that we are using a meteorological drought index (SPEI) and simulate population exposure to SPEI < -2 ("extreme drought") (Centre for Ecology and Hydrology 2016; Törnros and Menzel 2014). Although SPEI's long time scales (e.g., 24 months) are related to variations in groundwater storage (Vicente-Serrano et al. 2009), a comprehensive assessment of drought impacts may, nevertheless, require hydrology-related drought indices (Maskey and Trambauer 2015) and a study of groundwater resources (Green et al. 2011). Moreover, there is additional uncertainty associated with technological and socioeconomic changes, which will likely affect water usage, independent from the water surplus or deficit as measured by the SPEI in the present study.

\section{Results: global population exposure to extreme drought}

First, our SPEI-based projections of future drought (Fig. 1) are qualitatively similar to those of Orlowsky and Seneviratne (Orlowsky and Seneviratne 2013) who use the Standardized Precipitation Index (SPI) to predict increased droughts in the Mediterranean, South Africa and Central America/Mexico under RCP 8.5 for 2081-2100. The Mediterranean region is similarly highlighted in another paper (Prudhomme et al. 2014) although their projections for RCP 8.5 (for 2070-2099) are based on a hydrological drought model. Drought index maps for 
$2008-2017$

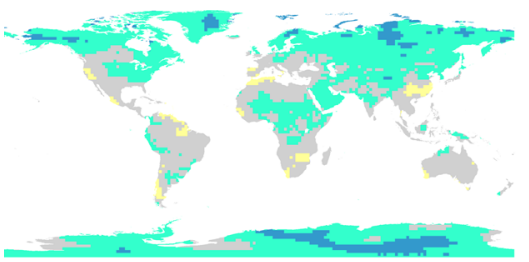

$2081-2100$

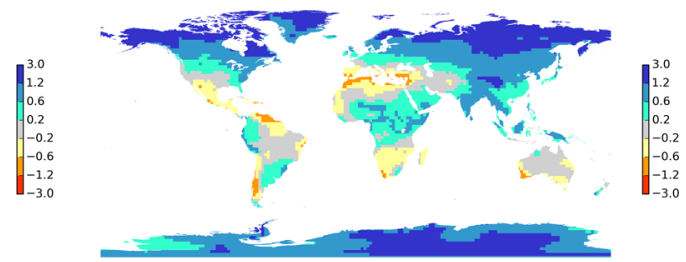

RCP 4.5
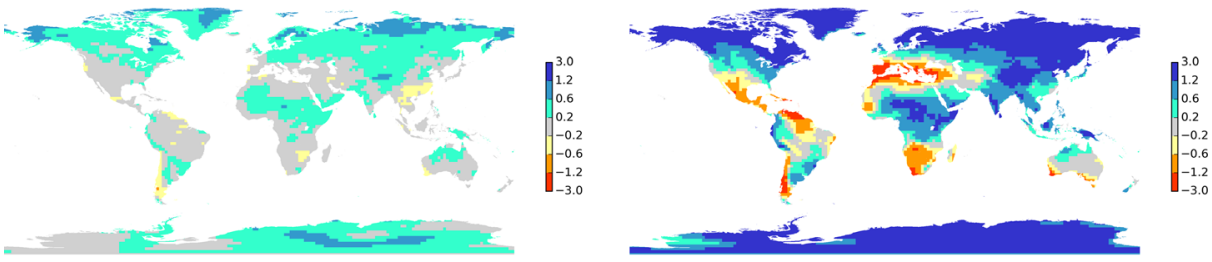

RCP 8.5

Fig. 1 Average monthly SPEI values. Displayed data are based on the mean values from our ensemble of 16 climate models. Negative values of the SPEI index represent drought conditions

the separate climate models under RCP 4.5 and RCP 8.5 are shown in Supplementary Information Figure 1. Both SPEI and the resulting population exposure projections (discussed below) are characterized by substantial regional uncertainty - meaning that using a large ensemble of climate models is necessary. For some regions, even a large ensemble of models may not sufficiently reduce regional uncertainty. In East Africa, for example, increased radiative forcing in CMIP5 models is associated with wetter conditions; however, the region has been dry in recent decades (Otieno and Anyah 2013; Shongwe et al. 2011; Yang et al. 2014, 2015).

Second, and speaking to our present interest, we find (Table 1) that, worldwide, the number of people exposed to extreme drought $(\mathrm{SPEI}<-2)$ will increase through the rest of this century under both the RCP 4.5 and RCP 8.5 emissions scenarios-with the largest divergence between those scenarios at the end of the century. More specifically, under RCP 4.5, the average monthly worldwide population predicted to be exposed to drought will increase between the periods 2008-2017 and 2018-2100 from the ensemble mean of 80.1 million to 211.7 million $(+164.3 \%)$ while under RCP 8.5, the equivalent increase will be from 89.7 million to 472.3 million ( $+426.5 \%)$.

In general, all 16 climate models used here predict that, globally, there will be more people exposed to extreme drought in the future than are so exposed at the present time. Furthermore, all models predict higher exposure for RCP 8.5 than RCP 4.5. However-and consistent with other studies (Schewe et al. 2014; Schmidhuber and Tubiello 2007)—we do find substantial variance in predictions among the 16 climate models in our ensemble. For example, under RCP 8.5, the global monthly population exposed to extreme drought during 2081-2100 is 110.2 million for the CNRM-CM5 model but 1145.5 million for IPSL-CM5A-MR (both far from the ensemble median of 431.4 million). Our use of the whole ensemble helps to reduce the uncertainties associated with such variation among individual models.

Our question concerns the relative role of population growth and anthropogenic climate change in causing the sharp increase in the number of people exposed to drought toward the end of the century (2081-2100). Addressing that, we conducted a simulation using four 
Table 1 Global monthly population exposed to extreme meteorological drought (in millions) for the ensemble of climate models

\begin{tabular}{|c|c|c|c|c|c|c|c|c|c|c|}
\hline & \multicolumn{5}{|l|}{$\mathrm{RCP} 4.5$} & \multicolumn{5}{|c|}{ RCP 8.5} \\
\hline & $\begin{array}{l}2008- \\
2017\end{array}$ & $\begin{array}{l}2021- \\
2040\end{array}$ & $\begin{array}{l}2041- \\
2060\end{array}$ & $\begin{array}{l}2061- \\
2080\end{array}$ & $\begin{array}{l}2081- \\
2100\end{array}$ & $\begin{array}{l}2008- \\
2017\end{array}$ & $\begin{array}{l}2021- \\
2040\end{array}$ & $\begin{array}{l}2041- \\
2060\end{array}$ & $\begin{array}{l}2061- \\
2080\end{array}$ & $\begin{array}{l}2081- \\
2100\end{array}$ \\
\hline ACCESS1-0 & 88.6 & 115.6 & 135.9 & 174.6 & 263.0 & 43.0 & 151.9 & 167.8 & 301.5 & 614.0 \\
\hline BCC-CSM1.1 & 58.6 & 105.5 & 85.9 & 104.5 & 107.7 & 55.9 & 93.2 & 172.5 & 223.8 & 369.7 \\
\hline$B N U-E S M$ & 86.8 & 117.0 & 166.8 & 186.4 & 229.7 & 160.9 & 161.5 & 292.6 & 363.5 & 543.9 \\
\hline CCSM4 & 48.0 & 95.1 & 106.8 & 122.7 & 174.6 & 51.6 & 132.8 & 161.1 & 316.9 & 428.2 \\
\hline CESM1-CAM5 & 94.0 & 153.2 & 177.0 & 202.7 & 228.8 & 86.1 & 90.3 & 150.2 & 196.5 & 236.9 \\
\hline CMCC-CM & 86.2 & 117.8 & 205.0 & 267.6 & 170.8 & 61.6 & 112.9 & 208.8 & 338.0 & 609.5 \\
\hline CNRM-CM5 & 81.3 & 104.9 & 60.9 & 48.5 & 67.2 & 134.3 & 76.8 & 75.6 & 93.9 & 110.2 \\
\hline CSIRO-Mk3-6-0 & 109.4 & 121.4 & 261.3 & 367.4 & 456.8 & 153.7 & 125.6 & 287.8 & 457.9 & 784.9 \\
\hline EC-EARTH & 82.9 & 121.9 & 138.7 & 168.2 & 335.2 & 84.0 & 85.4 & 156.5 & 301.6 & 422.5 \\
\hline$F G O A L S-g 2$ & 66.3 & 34.1 & 106.2 & 154.0 & 100.9 & 53.4 & 59.4 & 108.3 & 256.5 & 390.0 \\
\hline$G F D L-C M 3$ & 39.7 & 151.6 & 171.1 & 214.9 & 215.6 & 131.7 & 157.3 & 248.6 & 403.0 & 442.9 \\
\hline IPSL-CM5A-MR & 131.4 & 190.2 & 228.6 & 379.7 & 358.2 & 84.2 & 180.2 & 374.1 & 754.3 & 1145.5 \\
\hline MIROC5 & 91.3 & 82.3 & 128.0 & 135.4 & 166.7 & 68.0 & 84.8 & 122.8 & 222.6 & 316.1 \\
\hline$M P I-E S M-M R$ & 66.2 & 73.2 & 129.4 & 166.6 & 185.5 & 95.2 & 92.9 & 195.3 & 311.2 & 434.5 \\
\hline$M R I-C G C M 3$ & 83.1 & 95.6 & 129.3 & 121.2 & 135.7 & 79.8 & 103.8 & 126.7 & 162.0 & 196.9 \\
\hline NorESM1-M & 68.4 & 168.9 & 207.5 & 143.9 & 191.5 & 91.5 & 119.6 & 197.7 & 412.6 & 511.1 \\
\hline Median & 83.0 & 116.3 & 137.3 & 167.4 & 188.5 & 84.1 & 108.4 & 170.2 & 306.4 & 431.4 \\
\hline Mean & 80.1 & 115.5 & 152.4 & 184.9 & 211.7 & 89.7 & 114.3 & 190.4 & 319.7 & 472.3 \\
\hline St. Dev. & 22.5 & 38.1 & 54.0 & 88.7 & 102.0 & 36.9 & 34.7 & 77.7 & 150.6 & 245.9 \\
\hline Min & 39.7 & 34.1 & 60.9 & 48.5 & 67.2 & 43.0 & 59.4 & 75.6 & 93.9 & 110.2 \\
\hline Max & 131.4 & 190.2 & 261.3 & 379.7 & 456.8 & 160.9 & 180.2 & 374.1 & 754.3 & 1145.5 \\
\hline
\end{tabular}

The numbers represent the mean value for each time period (the value for each 20 year period is based on the mean for the corresponding 240 months). Both RCP 4.5 and RCP 8.5 are used in conjunction with the United Nations medium fertility population growth model to isolate the role of climate change. Under the RCP $8.5 / \mathrm{A} 2 \mathrm{r}$ population growth model, the population exposure values are higher by about $10 \%$ than in the table

conditions: (1) constant climate and constant population - the "constant world" model; (2) constant climate and growing population - the "population growth" model; (3) changing climate and constant population - the "climate change" model; and (4) changing climate and growing population - the "combined impacts" model. The "constant world" model is based on population data (United Nations, 2013) fixed at 2008 and climate projections for the 2008-2017 period. The "population growth" model keeps climate constant at the 2008-2017 projections while implementing the UN medium fertility population growth scenario (United Nations, 2013). The "climate change" model is based on population data fixed at 2008 but varies climate according to the ensemble of 16 CMIP5 climate models and the four emissions scenarios. Finally, the "combined impacts" model implements both population growth and changing climate. Figure 2 reports 2008-2100 projections for each of these conditions under RCP 8.5.

From Table 2, keeping climate change constant, the medium population growth scenario alone increases the average monthly number of people exposed to extreme drought from 85.5 to 121.0 million ( +35.5 million). Keeping population constant, climate change alone increases 


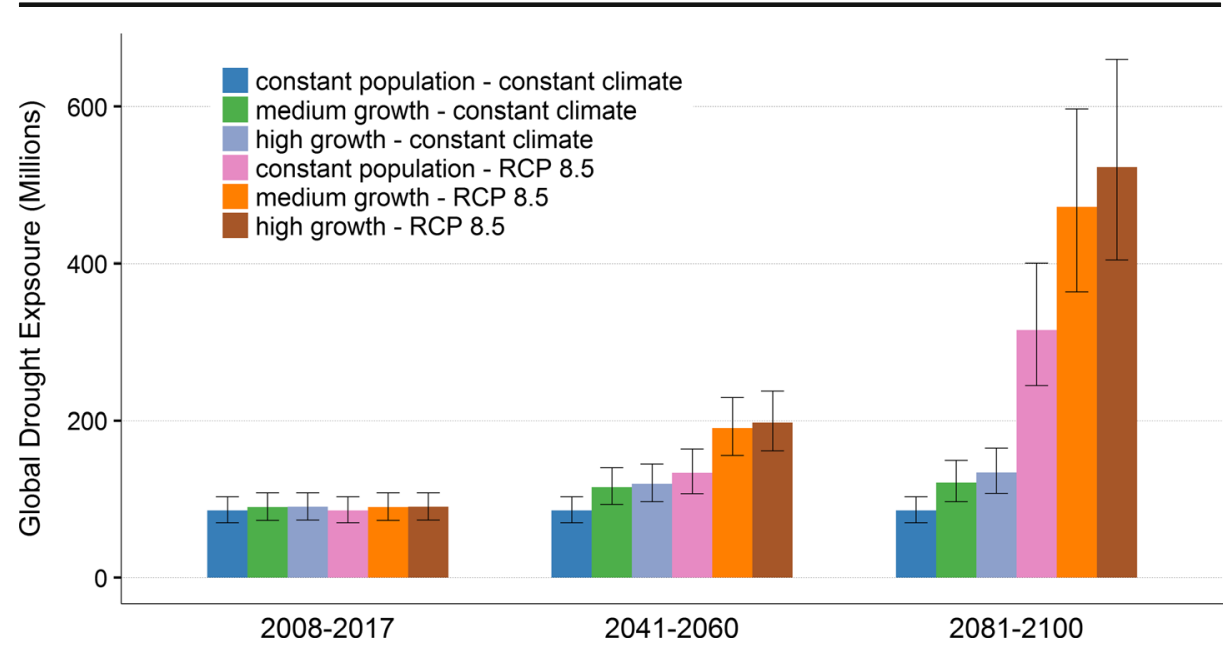

Fig. 2 Average monthly population exposed to extreme meteorological drought under RCP 8.5. The results are based on the mean values from the ensemble of 16 CMIP5 climate models. The error bars represent $90 \%$ confidence intervals

this number from 85.5 to 315.5 million (+230.0 million). Combining population growth and climate change, population exposure reaches 472.3 million $(+386.8$ million relative to the present). Dividing the impact of population growth by the combined impact of population growth and climate change shows that the former is responsible for only $9.2 \%$ of the increase in numbers exposed to extreme drought while, in the same terms, climate change alone accounts for $59.5 \%$ of the increase. The interaction between climate change and population growth explains the remaining $31.3 \%$ of change in population exposure-reflecting the fact that the growing population tends to be in regions with more frequent droughts.

The substantive results do not change under the higher (A2r) population growth scenario (Fig. 2; Supplementary Table 11). In this case, population growth accounts for $11.1 \%$ of the increase in global monthly exposure to extreme drought; climate change is responsible for $52.6 \%$; and the population growth and climate change interaction explains the remaining $36.4 \%$ of the total increase.

In the middle of the century (2041-2060), population growth plays a bigger role $(29.6 \%)$ but one that is still secondary to that of climate change $(48.1 \%)$. The smallest difference between the two sources of drought's population impact is for 2041-2060 under RCP 4.5 ( $23.9 \%$ and $29.4 \%$ for population growth and climate change respectively). By the end of the century, however, climate change plays the primary role even under RCP $4.5(54.8 \%$ of the combined impact versus $29.4 \%$ for population growth).

\section{Results: national populations exposure to extreme drought}

As might be expected, the relative impacts of population growth, climate change and the interaction of the two are not the same for all countries. In fact, in Fig. 3 we identify seven distinct types, or sets, of countries.

In Group 1 (which includes 19 countries - notably India, Vietnam and Bangladesh) climate change will decrease numbers exposed to extreme drought by increasing precipitation 
Table 2 Global population exposure to extreme drought

\begin{tabular}{|c|c|c|c|c|c|c|}
\hline Model & $\begin{array}{l}\text { Monthly exposed } \\
\text { population (millions) }\end{array}$ & $\begin{array}{l}\text { Increase } \\
\text { (millions) }\end{array}$ & $\begin{array}{l}\text { Share of } \\
\text { combined } \\
\text { increase }\end{array}$ & $\begin{array}{l}\text { Monthly exposed } \\
\text { population (millions) }\end{array}$ & $\begin{array}{l}\text { Increase } \\
\text { (millions) }\end{array}$ & $\begin{array}{l}\text { Share of } \\
\text { combined } \\
\text { increase }\end{array}$ \\
\hline & 2041-2060: RCP 4.5 & & & 2041-2060: RCP 8.5 & & \\
\hline $\begin{array}{c}\text { Constant } \\
\text { world }\end{array}$ & $76.1(66.2-86.4)$ & 0.0 & & $85.5(69.6-102.9)$ & 0.0 & \\
\hline $\begin{array}{l}\text { Population } \\
\text { growth }\end{array}$ & $100.0(86.3-114.3)$ & 23.9 & $31.3 \%$ & $115.1(93.1-140.1)$ & 29.6 & $28.2 \%$ \\
\hline $\begin{array}{l}\text { Climate } \\
\text { change }\end{array}$ & $105.6(87.9-123.9)$ & 29.4 & $38.6 \%$ & $133.6(106.7-164.0)$ & 48.1 & $45.8 \%$ \\
\hline \multirow{2}{*}{$\begin{array}{r}\text { Combined } \\
\text { impacts }\end{array}$} & $152.4(127.4-178.3)$ & 76.3 & $100.0 \%$ & $190.4(155.7-229.1)$ & 104.9 & $100.0 \%$ \\
\hline & 2081-2100: RCP 4.5 & & & 2081-2100: RCP 8.5 & & \\
\hline $\begin{array}{c}\text { Constant } \\
\text { world }\end{array}$ & $76.1(66.2-86.4)$ & 0.0 & & $85.5(69.6-102.9)$ & 0.0 & \\
\hline $\begin{array}{c}\text { Population } \\
\text { growth }\end{array}$ & $104.3(88.1-122.0)$ & 28.2 & $20.8 \%$ & $121.0(96.5-149.5)$ & 35.5 & $9.2 \%$ \\
\hline $\begin{array}{l}\text { Climate } \\
\text { change }\end{array}$ & $130.9(103.9-160.6)$ & 54.8 & $40.4 \%$ & $315.5(244.5-401.1)$ & 230.0 & $59.5 \%$ \\
\hline $\begin{array}{r}\text { Combined } \\
\text { impacts }\end{array}$ & $211.7(166.1-262.5)$ & 135.6 & $100.0 \%$ & $472.3(364.4-596.8)$ & 386.8 & $100.0 \%$ \\
\hline
\end{tabular}

The results are based on the mean values from the ensemble of 16 CMIP5 climate models (the range in parentheses represents $90 \%$ confidence interval obtained by means of bootstrapping). Population growth is responsible for $(\mathrm{PG}-\mathrm{CW}) /(\mathrm{CI}-\mathrm{CW})$ share of the total increase in global population exposure to extreme drought, where PG is the exposure under population growth model only; $\mathrm{CW}$ is the constant world without population growth and climate change; and $\mathrm{CI}$ is the model that includes both population growth and climate change. Similarly, climate change is responsible for $(\mathrm{CC}-\mathrm{CW}) /(\mathrm{CI}-\mathrm{CW})$ share of the total increase, where $\mathrm{CC}$ is the exposure under climate change and fixed population

(see Fig. 1; Supplementary Table 3 provides descriptive statistics and details about the important case of India in this respect). For these countries, the impact of population growth is smaller relative to the impact of climate change and, thus, the net change in exposure is negative.

Group 2 includes 7 countries (e.g., the Philippines, Malaysia, and Rwanda) in which climate change alone similarly decreases numbers exposed to extreme drought but not sufficiently to prevent a net increase in numbers so exposed as a result of high population growth.

Group 3 consists of three outliers - Japan, Taiwan and Russia. While extreme drought conditions are projected to increase for these three nations, substantial negative population growth will result in a decrease of numbers exposed to such drought. China would have belonged to this group had we used predictions from a median climate model as opposed to the ensemble mean (see Supplementary Table 4 for details).

Group 4 is the second largest containing 54 nations. These are predicted to experience negative population growth yet also a net increase in numbers exposed to extreme drought. China belongs in this set, but notice that the total increase in numbers exposed to extreme drought there $(+598.4$ thousand every month) is relatively small since the impact of negative population growth $(-3414.9)$ and the interaction of that with climate change $(-895.2)$ 


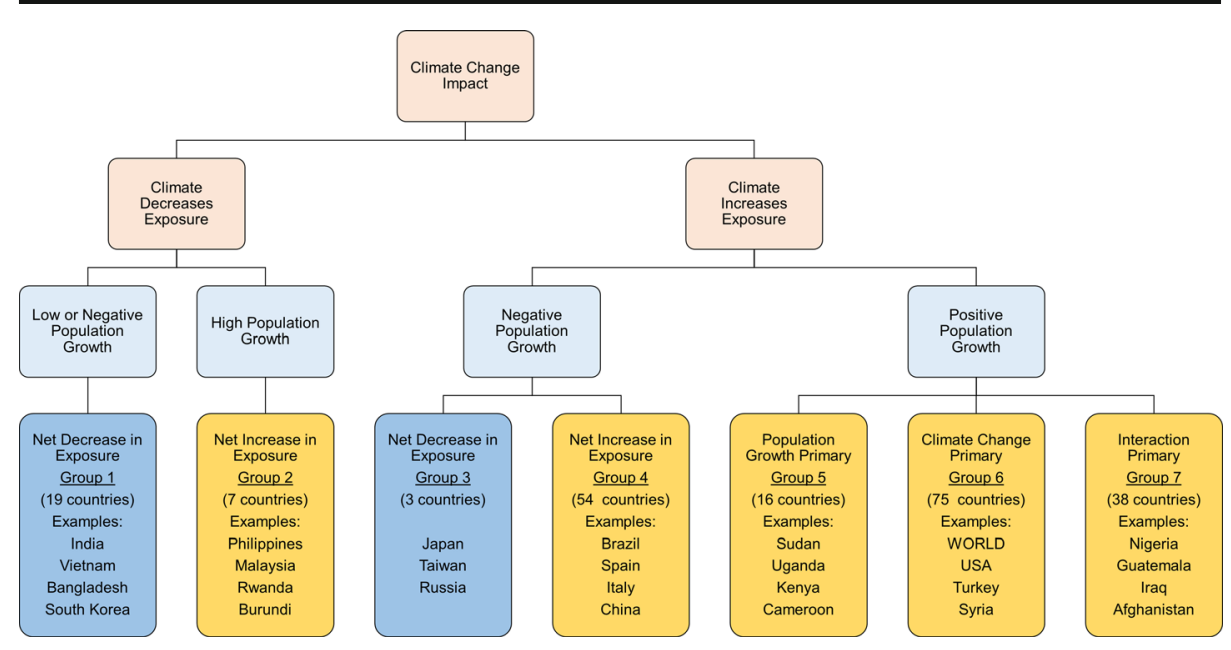

Fig. 3 Classification of national populations by the relative impacts of population growth, climate change, and the net population exposure to extreme drought under RCP 8.5 by the end of the century (2081-2100). The results are based on the mean average monthly population exposure calculated from the ensemble of 16 climate models. The calculations of relative impacts are based on the above four simulated conditions, viz. (1) constant world, (2) constant climate, population growth, (3) climate change, constant population and (4) climate change and population growth - as described above in detail

alleviated most of climate change's impact (+4908.5). On the other hand, in Brazil and Spain climate change dominates the increase in numbers exposed to extreme drought (Table 3).

Nations in Groups 5, 6, and 7 all experience both positive population growth and increased drought conditions (climate change in isolation). The groups differ according to the factor that is responsible for the largest share of the total increase in population exposure to droughtspecifically population growth (in Group 5), climate change (in Group 6), and their interaction (in Group 7).

We observe that Group 5 is relatively small, composed of mostly African nations with very high population growth and relatively modest increase in drought conditions. We conjecture that, for these countries, socioeconomic development and the decreases in population growth that it may bring could alleviate the impact of future droughts.

Group 6 is the largest one, including 75 countries - with the world as a whole matching the criteria for this group. For these countries (as for the world as a whole), climate change alone explains the largest share of the increase in drought exposure. For example, in the United States, which belongs to this group, climate change is responsible for $61.3 \%$ of the increase in numbers exposed to extreme drought while population growth accounts for only $12.5 \%$ of that increase and the population growth-climate change interaction for the remaining $26.2 \%$. Notice that, together with Group 4 (negative population growth, net positive increase in exposure), these nations' projections indicate that it is climate change rather than population growth that is the reason for worse drought conditions. Finally, both climate change and population growth play important roles for countries in Group 7, leading to an interaction between (high) population growth and a substantial increase in extreme drought conditions as the primary cause for the increased numbers of their citizens exposed to drought. For example, in Nigeria the population growth-climate change interaction is responsible for $62.7 \%$ of the total impact; in Mali for $83.1 \%$; and in Senegal for $74.2 \%$. 
Table 3 National populations' exposure to extreme meteorological drought during 2081-2100 under RCP 8.5 for the top 15 nations

\begin{tabular}{|c|c|c|c|c|c|c|}
\hline Country & $\begin{array}{l}\text { Monthly } \\
\text { Exposed } \\
\text { population } \\
\text { (thousands) }\end{array}$ & $\begin{array}{l}\text { Uncertainty (95\% } \\
\text { C.I.) (thousands) }\end{array}$ & $\begin{array}{l}\text { Total increase } \\
\text { relative to } \\
\text { constant world } \\
\text { (thousands) }\end{array}$ & $\begin{array}{l}\text { Increase due } \\
\text { to population } \\
\text { growth } \\
\text { (thousands) }\end{array}$ & $\begin{array}{l}\text { Increase due } \\
\text { to climate } \\
\text { change } \\
\text { (thousands) }\end{array}$ & $\begin{array}{l}\text { Increase due to } \\
\text { PG and CC } \\
\text { interaction } \\
\text { (thousands) }\end{array}$ \\
\hline Nigeria & $22,966.6$ & $(6030.3-44,459.5)$ & $21,831.2$ & 5050.5 & 3099.6 & $13,681.2$ \\
\hline Turkey & $22,258.1$ & $(13,687.6-31,602.4)$ & $21,182.0$ & 184.7 & $17,547.9$ & 3449.4 \\
\hline China & $19,605.3$ & $(5450.8-45,040.2)$ & 598.4 & -3414.9 & 4908.5 & -895.2 \\
\hline Algeria & $19,198.3$ & $(14,057.3-24,418.0)$ & $18,185.9$ & 517.6 & $11,672.0$ & 5996.3 \\
\hline Mexico & $19,152.1$ & $(10,471.7-29,732.5)$ & $17,483.5$ & 319.7 & $14,422.1$ & 2741.6 \\
\hline Morocco & $17,258.0$ & $(12,991.3-21,872.6)$ & $16,651.2$ & 216.3 & $12,197.9$ & 4237.0 \\
\hline Egypt & $15,929.8$ & $(8754.6-25,213.1)$ & $15,281.9$ & 520.7 & 8186.2 & 6575.0 \\
\hline Brazil & $15,710.6$ & $(9555.2-22,544.9)$ & $13,063.1$ & -163.4 & $14,150.5$ & -924.0 \\
\hline Venezuela & $14,989.7$ & $(8024.4-22,478.3)$ & $13,838.9$ & 562.3 & 8963.7 & 4312.9 \\
\hline USA & $14,945.4$ & $(7399.7-23,910.7)$ & $11,465.3$ & 1432.9 & 7028.3 & 3004.0 \\
\hline Indonesia & $11,542.4$ & $(2291.1-24,586.5)$ & 6117.0 & 1888.6 & 3160.5 & 1067.9 \\
\hline Spain & $10,831.2$ & $(7453.7-14,602.2)$ & 9736.6 & -147.8 & $11,530.5$ & -1646.1 \\
\hline Mali & $10,474.2$ & $(4776.1-17,229.4)$ & $10,451.6$ & 99.3 & 1669.7 & 8682.6 \\
\hline Senegal & $10,456.2$ & $(5512.1-15,953.7)$ & $10,361.4$ & 299.5 & 2377.2 & 7684.7 \\
\hline Syria & 9901.7 & $(6628.0-13,484.3)$ & 9553.6 & 290.4 & 5003.5 & 4259.7 \\
\hline India & 9731.4 & $(3144.8-18,585.0)$ & -2489.4 & 4072.3 & -4928.8 & -1632.8 \\
\hline Italy & 9520.1 & $(6500.1-13,133.1)$ & 8737.5 & -101.6 & $10,162.5$ & -1323.4 \\
\hline Guatemala & 8584.4 & $(3392.1-14,854.3)$ & 8431.8 & 344.9 & 2504.5 & 5582.3 \\
\hline France & 8456.9 & $(5204.7-11,907.6)$ & 8145.8 & 57.7 & 6802.3 & 1285.8 \\
\hline Iraq & 8456.0 & $(4138.9-13,848.7)$ & 7767.7 & 1653.9 & 1783.0 & 4330.7 \\
\hline
\end{tabular}

The results are based on the mean values from the ensemble of 16 CMIP5 climate models. Top 20 nations with the largest average monthly population exposed to extreme meteorological drought (combined impacts of population growth and climate change). $95 \%$ confidence intervals are obtained by means of bootstrapping

\section{Conclusion}

Projections of exposure to future climate impacts are associated with multiple sources of uncertainty inherent in climate models' predictions, emissions scenarios, groundwater resources, population growth trends, and generally unpredictable technological, social and security changes. Acknowledging this uncertainty, we simulate population exposure to extreme drought throughout the twenty-first century under different emissions scenarios. Consistent with the most recent Assessment Report by the IPCC (IPCC 2014), we focus on 2041-2060 and 2081-2100 periods examining the relative contributions of climate change and population growth to increases in drought exposure globally and also for individual nations.

An emerging consensus in the current literature on water scarcity (Arnell and LloydHughes 2014; Arnell 2004; Arnell et al. 2011; Gerten et al. 2011; Rockström et al. 2009; Vörösmarty et al. 2000), as well as the IPCC report (IPCC 2014), implies that future water scarcity will by primarily caused by population growth and only secondarily by climate change (Gerten et al. 2011; Schewe et al. 2014). For policy-makers, these conclusions may imply, in 
turn, that focusing on economic development and, consequently, slower population growth, should be the political priority.

Here we look at the population exposure to extreme drought using a meteorological drought index, SPEI-24, which at a 24-month time scale is also related to variations in groundwater storage (Vicente-Serrano et al. 2009), finding that climate change plays the main role in predicting future exposure to extreme droughts (the number of people living in grid cells with SPEI $<-2$ ). Under RCP 8.5 and during the period 2081-2100, in global terms climate change alone is responsible for $59.5 \%$ of drought exposure, with the climate change and population growth interaction accounting for $31.4 \%$. Population growth alone causes a relatively minor $9.2 \%$ increase. Similarly, climate change is the main source of increasing drought exposure in 129 countries - by comparison with only 23 countries where the drought exposure will rise due to population growth.

We caution that our numerical projections should not be taken literally given the very large uncertainties mentioned above. Nevertheless, the emerging picture and its political implications are both clear: Climate change mitigation should be the main policy response in efforts to alleviate numbers exposed to future extreme droughts. For the world as a whole - as well as for a substantial majority of its national populations - plausible future decreases in population growth will not make a major dent in the very large increase of numbers likely to be exposed to extreme drought through the rest of this century. Overwhelmingly, future increases in humans' exposure to extreme drought will be a consequence of anthropogenic climate change.

Open Access This article is distributed under the terms of the Creative Commons Attribution 4.0 International License (http://creativecommons.org/licenses/by/4.0/), which permits unrestricted use, distribution, and reproduction in any medium, provided you give appropriate credit to the original author(s) and the source, provide a link to the Creative Commons license, and indicate if changes were made.

\section{References}

Arnell NW (2004) Climate change and global water resources: SRES emissions and socio-economic scenarios. Glob Environ Chang 14(1):31-52. doi:10.1016/j.gloenvcha.2003.10.006

Arnell N, Lloyd-Hughes B (2014) The global-scale impacts of climate change on water resources and flooding under new climate and socio-economic scenarios. Clim Chang 122(1-2):127-140. doi:10.1007/s10584-0130948-4

Arnell NW, van Vuuren DP, Isaac M (2011) The implications of climate policy for the impacts of climate change on global water resources. Glob Environ Chang 21(2):592-603. doi:10.1016/j.gloenvcha.2011.01.015

Bhaduri B, Bright E, Coleman P, Urban M (2007) LandScan USA: a high-resolution geospatial and temporal modeling approach for population distribution and dynamics. GeoJournal 69(1-2):103-117. doi:10.1007/ s10708-007-9105-9

Centre for Ecology and Hydrology (2016) UK Droughts: SPEI Retrieved from https://eip.ceh.ac.uk/apps/ droughts/spei.html

Dilley M (2005) Natural disaster hotspots: a global risk analysis (Vol. 5): World Bank Publications

Gerten D, Heinke J, Hoff H, Biemans H, Fader M, Waha K (2011) Global water availability and requirements for future food production. J Hydrometeorol 12(5):885-899. doi:10.1175/2011JHM1328.1

Gosling S, Arnell N (2013) A global assessment of the impact of climate change on water scarcity. Clim Chang: 1-15. doi:10.1007/s10584-013-0853-x

Green TR, Taniguchi M, Kooi H, Gurdak JJ, Allen DM, Hiscock KM, Aureli A (2011) Beneath the surface of global change: Impacts of climate change on groundwater. J Hydrol 405(3-4):532-560. doi:10.1016/j. jhydrol.2011.05.002

Hanasaki N, Fujimori S, Yamamoto T, Yoshikawa S, Masaki Y, Hijioka Y, Kanae S (2013) A global water scarcity assessment under shared socio-economic pathways \&ndash; part 2: water availability and scarcity. Hydrol Earth Syst Sci 17(7):2393-2413. doi:10.5194/hess-17-2393-2013 
Hijmans, R., Garcia, N., Wieczorek, J., \& Rala, A. (2011). Global Administrative Areas (GADM). Retrieved from: http://www.gadm.org/

Hinkel J, Vuuren D, Nicholls R, Klein RT (2013) The effects of adaptation and mitigation on coastal flood impacts during the twenty-first century. An application of the DIVA and IMAGE models. Clim Chang 117(4):783-794. doi:10.1007/s10584-012-0564-8

IPCC (2013) Climate change 2013: the physical science basis. Contribution of working group I to the fifth assessment report of the intergovernmental panel on climate change. Retrieved from Cambridge, United Kingdom and New York, NY, USA

IPCC (2014) Climate change 2014: impacts, adaptation, and vulnerability. Part A: global and sectoral aspects. Contribution of working group II to the fifth assessment report of the intergovernmental panel on climate change. Retrieved from Cambridge, United Kingdom and New York, NY, USA

Kelley CP, Mohtadi S, Cane MA, Seager R, Kushnir Y (2015) Climate change in the fertile crescent and implications of the recent Syrian drought. Proc Natl Acad Sci. doi:10.1073/pnas.1421533112

Kummu M, Ward PJ, de Moel H, Varis O (2010) Is physical water scarcity a new phenomenon? Global assessment of water shortage over the last two millennia. Environ Res Lett 5(3):034006

Maraun D, Wetterhall F, Ireson AM, Chandler RE, Kendon EJ, Widmann M, Thiele-Eich I (2010) Precipitation downscaling under climate change: Recent developments to bridge the gap between dynamical models and the end user. Rev Geophys 48(3). doi:10.1029/2009RG000314

Maskey S, Trambauer P (2015) Hydrological modeling for drought assessment. In: Shroder JF, Paron P, Di Baldassarre G (eds) Hydro-meteorological hazards, risks, and disasters. Elsevier, Amsterdam

McKee TB, Doeskin NJ, Kleist J (1993) The relationship of drought frequency and duration to time scales. Paper presented at the 8th Conf. on Applied Climatology, Anaheim

Mishra AK, Singh VP (2010) A review of drought concepts. J Hydrol 391(1-2):202-216. doi:10.1016/j.jhydrol. 2010.07.012

Moss RH, Edmonds JA, Hibbard KA, Manning MR, Rose SK, van Vuuren DP, et al. (2010) The next generation of scenarios for climate change research and assessment. Nature 463(7282):747-756 http://www.nature. com/nature/journal/v463/n7282/suppinfo/nature08823_S1.html

Orlowsky B, Seneviratne SI (2013) Elusive drought: uncertainty in observed trends and short- and long-term CMIP5 projections. Hydrol Earth Syst Sci 17(5):1765-1781. doi:10.5194/hess-17-1765-2013

Otieno VO, Anyah RO (2013) CMIP5 simulated climate conditions of the greater horn of Africa (GHA). Part 1: contemporary climate. Clim Dyn 41(7):2081-2097. doi:10.1007/s00382-012-1549-z

Palmer WC (1965) Meteorological Drought: U.S. Department of Commerce, Weather Bureau, Washington, D.C.

Potop V, Boroneanț C, Možný M, Štěpánek P, Skalák P (2013) Observed spatiotemporal characteristics of drought on various time scales over the Czech Republic. Theor Appl Climatol:1-19. doi:10.1007/s00704-013-0908-y

Prudhomme C, Giuntoli I, Robinson EL, Clark DB, Arnell NW, Dankers R, Wisser D (2014) Hydrological droughts in the twenty-first century, hotspots and uncertainties from a global multimodel ensemble experiment. Proc Natl Acad Sci 111(9):3262-3267. doi:10.1073/pnas.1222473110

Reyna SP (2010) The disasters of war in Darfur, 1950-2004. Third World Q 31(8):1297-1320. doi:10.1080/ 01436597.2010 .541083

Rockström J, Falkenmark M, Karlberg L, Hoff H, Rost S, Gerten D (2009) Future water availability for global food production: The potential of green water for increasing resilience to global change. Water Resour Res 45(7):W00A12. doi:10.1029/2007WR006767

Schewe J, Heinke J, Gerten D, Haddeland I, Arnell NW, Clark DB, Kabat P (2014) Multimodel assessment of water scarcity under climate change. Proc Natl Acad Sci 111(9):3245-3250. doi:10.1073/pnas.1222460110

Schmidhuber J, Tubiello FN (2007) Global food security under climate change. Proc Natl Acad Sci 104(50): 19703-19708. doi:10.1073/pnas.0701976104

Shongwe ME, Oldenborgh GJV, Hurk BVD, Aalst MV (2011) Projected changes in mean and extreme precipitation in Africa under global warming. Part II: East Africa. J Clim 24(14):3718-3733. doi:10.1175/ 2010JCLI2883.1

Svoboda M, LeComte D, Hayes M, Heim R, Gleason K, Angel J, Stooksbury D (2002) The drought monitor. Bull Am Meteorol Soc 83(8):1181-1190

Taylor KE, Stouffer RJ, Meehl GA (2011) An overview of CMIP5 and the experiment design. Bull Am Meteorol Soc 93(4):485-498. doi:10.1175/BAMS-D-11-00094.1

Teutschbein C, Seibert J (2012) Bias correction of regional climate model simulations for hydrological climatechange impact studies: review and evaluation of different methods. J Hydrol 456-457:12-29. doi:10.1016/j. jhydrol.2012.05.052

Thornthwaite CW (1948) An approach toward a rational classification of climate. Geogr Rev 38(1):55-94. doi: $10.2307 / 210739$

Törnros T, Menzel L (2014) Addressing drought conditions under current and future climates in the Jordan River region. Hydrol Earth Syst Sci 18(1):305-318. doi:10.5194/hess-18-305-2014 
United Nations, D. O. E. A. S. A., Population Division (2013) World Population Prospects: The 2012 Revision Retrieved from: http://esa.un.org/wpp/Excel-Data/population.htm

Vicente-Serrano SM, Beguería S, López-Moreno JI (2009) A multiscalar drought index sensitive to global warming: the standardized precipitation evapotranspiration index. J Clim 23(7):1696-1718. doi:10.1175/ 2009JCLI2909.1

Vörösmarty CJ, Green P, Salisbury J, Lammers RB (2000) Global water resources: vulnerability from climate change and population growth. Science 289(5477):284-288. doi:10.1126/science.289.5477.284

Vuuren DP, Stehfest E, Elzen MGJ, Kram T, Vliet J, Deetman S, Ruijven B (2011) RCP2.6: exploring the possibility to keep global mean temperature increase below $2{ }^{\circ} \mathrm{C}$. Clim Chang 109(1-2):95-116. doi:10. 1007/s10584-011-0152-3

Watts, N., Adger, W. N., Agnolucci, P., Blackstock, J., Byass, P., Cai, W., Costello, A. (2015) Health and climate change: policy responses to protect public health. Lancet. doi:10.1016/S0140-6736(15)60854-6

Yang W, Seager R, Cane MA, Lyon B (2014) The east African long rains in observations and models. J Clim 27(19):7185-7202. doi:10.1175/JCLI-D-13-00447.1

Yang W, Seager R, Cane MA, Lyon B (2015) The rainfall annual cycle bias over East Africa in CMIP5 coupled climate models. J Clim 28(24):9789-9802. doi:10.1175/JCLI-D-15-0323.1 